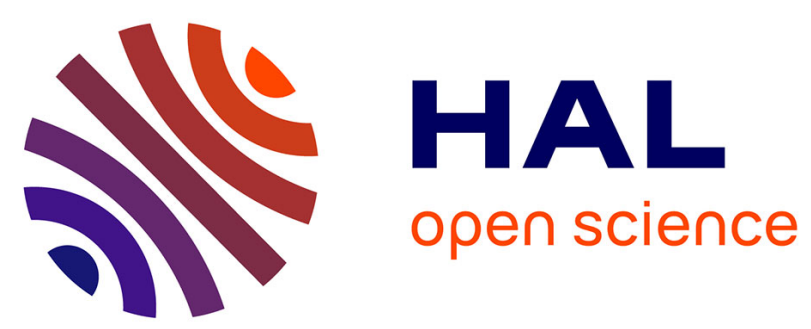

\title{
Silicon isotope ratio measurements by inductively coupled plasma tandem mass spectrometry for alteration studies of nuclear waste glasses
}

\author{
A. Gourgiotis, T. Ducasse, E. Barker, Patrick Jollivet, S. Gin, Sylvain Bassot, \\ Charlotte Cazala
}

\section{To cite this version:}

A. Gourgiotis, T. Ducasse, E. Barker, Patrick Jollivet, S. Gin, et al.. Silicon isotope ratio measurements by inductively coupled plasma tandem mass spectrometry for alteration studies of nuclear waste glasses. Analytica Chimica Acta, 2017, 954, pp.68-76. 10.1016/j.aca.2016.11.063 . hal-02551306

\author{
HAL Id: hal-02551306 \\ https://hal.science/hal-02551306
}

Submitted on 5 Jun 2020

HAL is a multi-disciplinary open access archive for the deposit and dissemination of scientific research documents, whether they are published or not. The documents may come from teaching and research institutions in France or abroad, or from public or private research centers.
L'archive ouverte pluridisciplinaire HAL, est destinée au dépôt et à la diffusion de documents scientifiques de niveau recherche, publiés ou non, émanant des établissements d'enseignement et de recherche français ou étrangers, des laboratoires publics ou privés.

\section{(ㅇ)(1) $\$$}

Distributed under a Creative Commons Attribution - NonCommercial - NoDerivatives 44.0 


\section{Figure}

Click here to download Figure: Figures revised versi

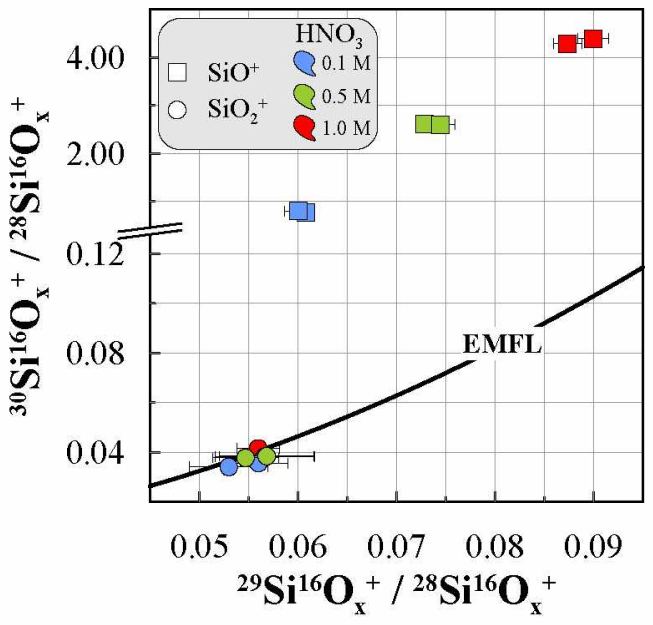

Fig.1 


\section{Q1 (m/z) ORS Q2 (m/z)}
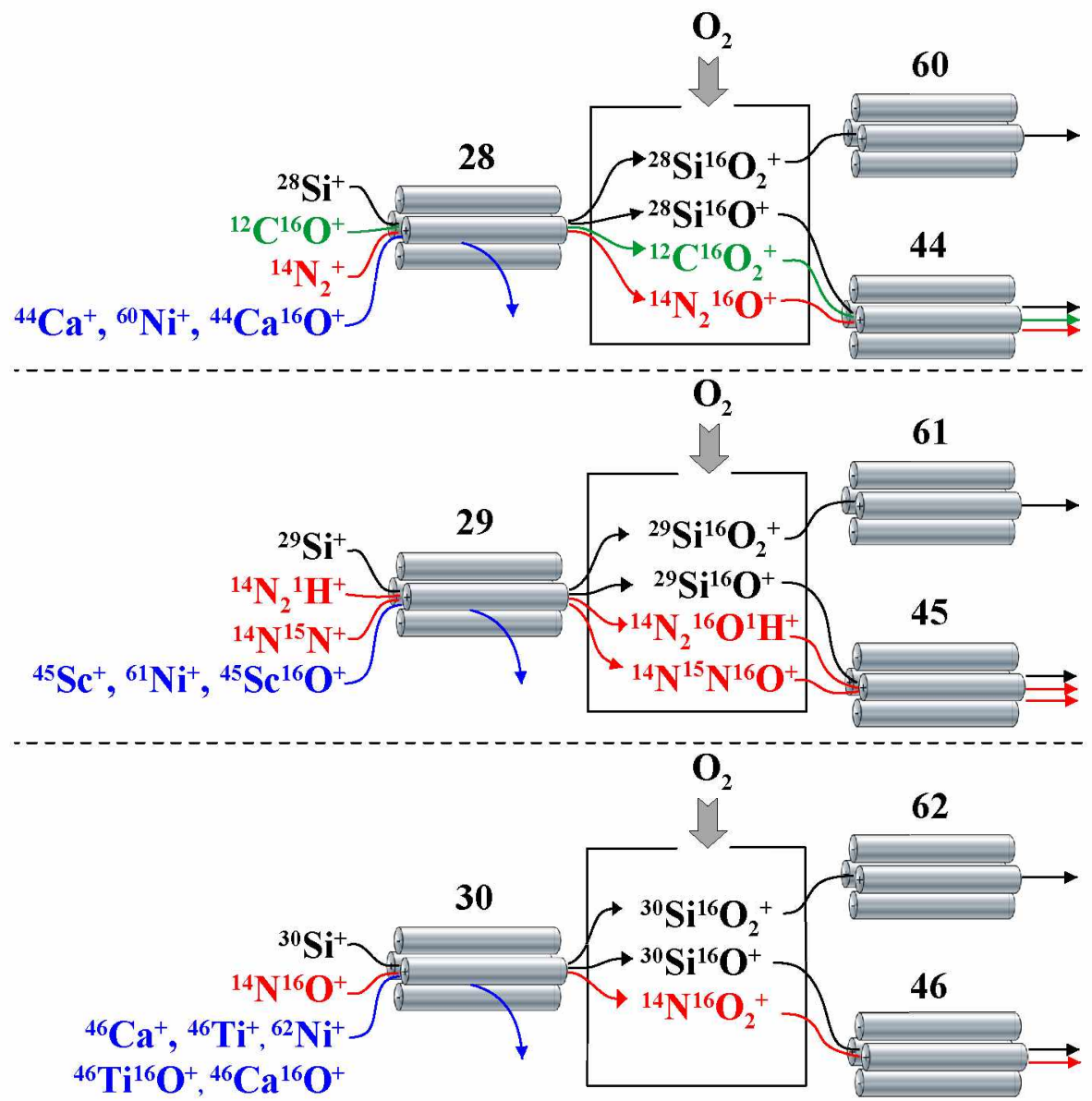

Fig.2 

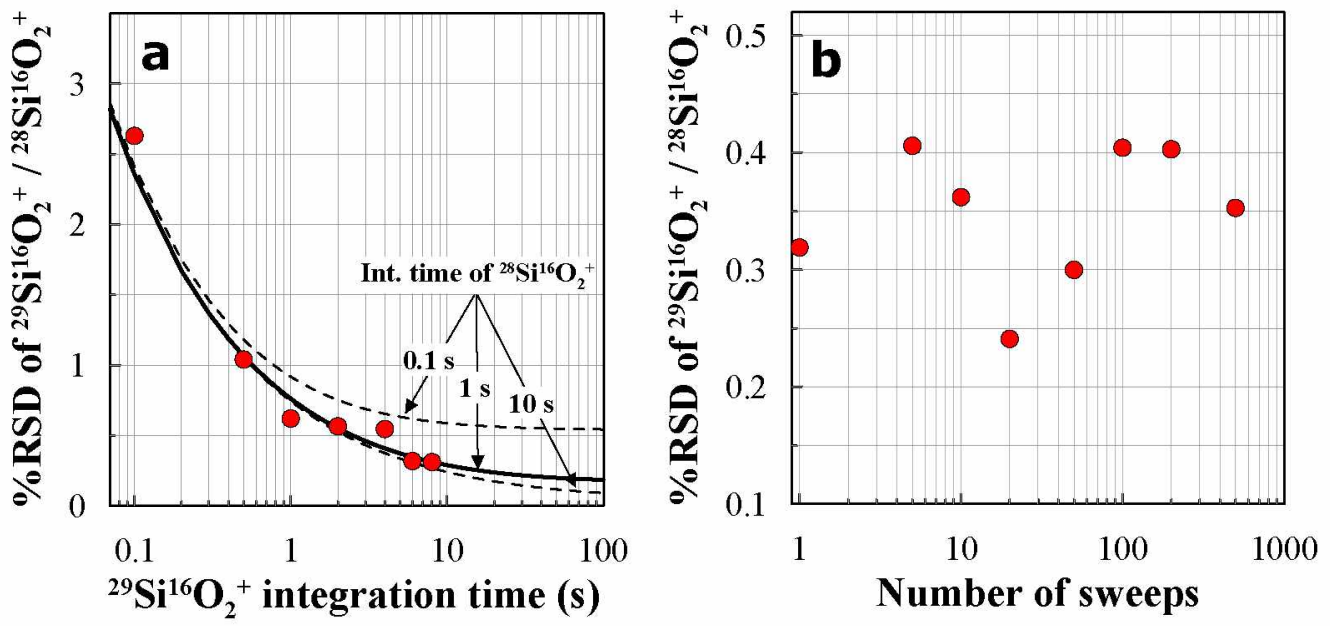

Fig.3 


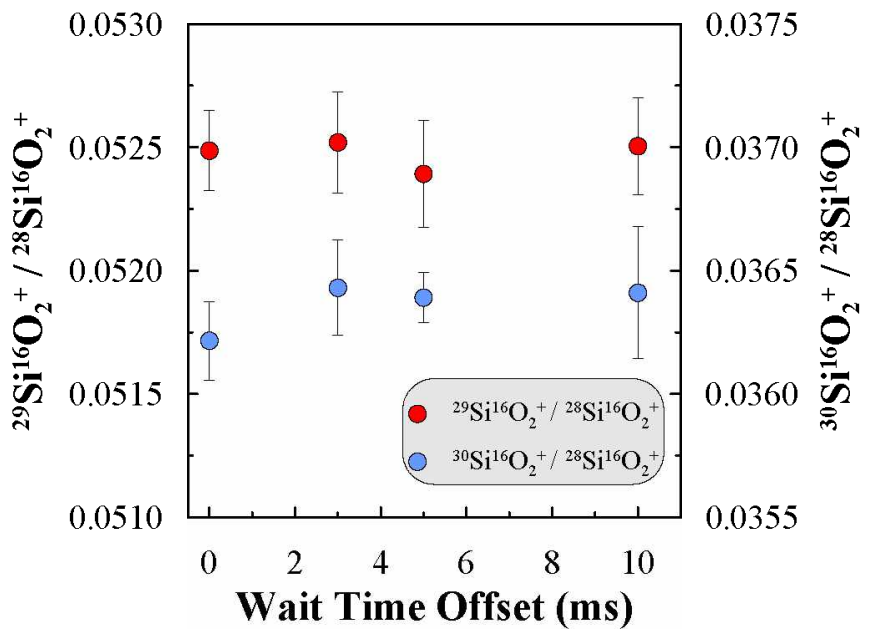

Fig.4 


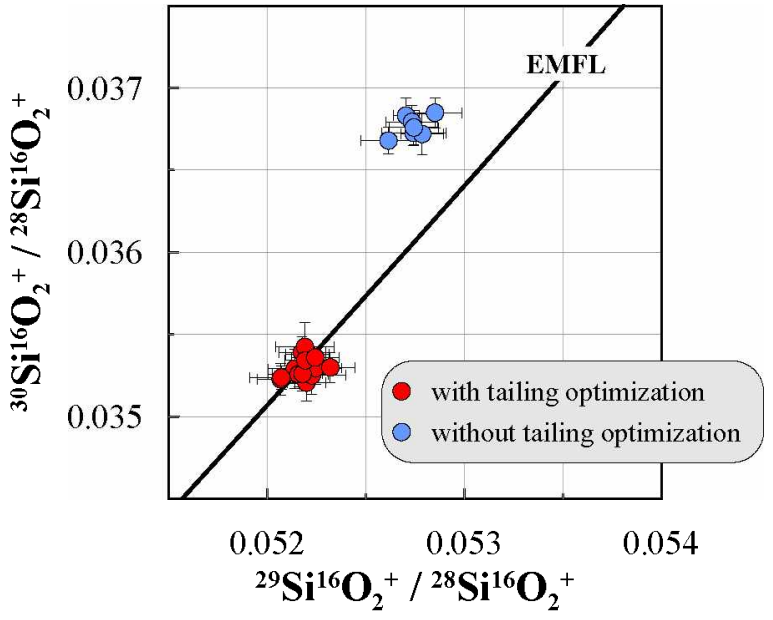

Fig.5 

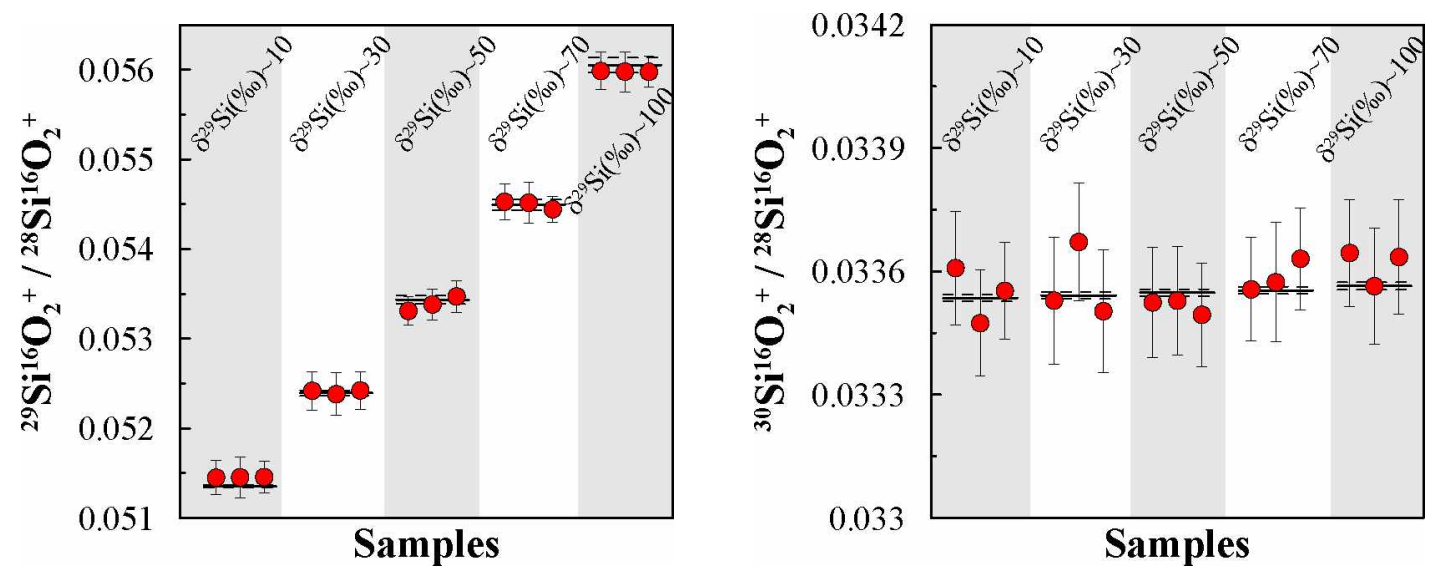

Fig.6 
4 Silicon isotope ratio measurements by inductively coupled plasma tandem $5 \quad$ mass spectrometry for alteration studies of nuclear waste glasses

11 Gourgiotis Alkiviadis ${ }^{1}$, Ducasse Thomas ${ }^{2}$, Barker Evelyne $^{1}$, Jollivet Patrick ${ }^{2}$, Gin Stephane ${ }^{2}$, 12 Bassot Sylvain ${ }^{1}$, Cazala Charlotte ${ }^{1}$

151 : Institut de Radioprotection et de Sûreté Nucléaire (IRSN)

16 PRP-DGE/SRTG/LT2S

2 : CEA, DEN, DTCD, SECM, F-30207 Bagnols-sur-Ceze, France

19 Keywords

20 Silicon isotope ratios, triple quadrupole, ICP-QQQ, ICP-MS/MS, nuclear glasses, tandem 21 mass spectrometry 


\section{Abstract}

High-level long-lived nuclear waste arising from spent fuel reprocessing is vitrified in silicate glasses for final disposal in deep geologic formations. In order to better understand the mechanisms driving glass dissolution, glass alteration studies, based on silicon isotope ratio monitoring of ${ }^{29} \mathrm{Si}$-doped aqueous solutions, were carried out in laboratories.

In this work were explored the capabilities of the new type of quadrupole-based ICP-MS, the Agilent 8800 tandem quadrupole ICP-MS/MS, for accurate silicon isotope ratio determination for alteration studies of nuclear waste glasses. In order to avoid silicon polyatomic interferences a new analytical method was developed using $\mathrm{O}_{2}$ as the reaction gas in the Octopole Reaction System (ORS), and silicon isotopes were measured in mass-shift mode. A careful analysis of the potential polyatomic interferences on $\mathrm{SiO}^{+}$and $\mathrm{SiO}_{2}{ }^{+}$ion species was performed, and we found that $\mathrm{SiO}^{+}$ion species suffer from important polyatomic interferences coming from the matrix of sample and standard solutions $\left(0.5 \mathrm{M} \mathrm{HNO}_{3}\right)$. For $\mathrm{SiO}_{2}{ }^{+}$no interferences were detected and thus these ion species were chosen for silicon isotope ratio determination. A number of key settings for accurate isotope ratio analysis like, detector dead time, integration time, number of sweeps, wait time offset, memory blank and instrumental mass fractionation, were considered and optimized. Particular attention was paid to the optimization of abundance sensitivity of the quadrupole mass filter before the ORS. We showed that poor abundance sensitivity leads to a significant shift of the data away from the Exponential Mass Fractionation Law (EMFL) due to the spectral overlaps of silicon isotopes combined with different oxygen isotopes (i.e. ${ }^{28} \mathrm{Si}^{16} \mathrm{O}^{18} \mathrm{O}^{+},{ }^{30} \mathrm{Si}^{16} \mathrm{O}^{16} \mathrm{O}^{+}$). The developed method was validated by measuring a series of reference solutions with different ${ }^{29} \mathrm{Si}$ enrichment. Isotope ratio trueness, uncertainty and repeatability were found to be $<0.2 \%$, $<0.5 \%$ and $<0.6 \%$, respectively. These performances meet the requirements of the studies of nuclear glasses alteration and open up possibilities to use this method for precise determination of silicon content in natural samples by Isotope Dilution. 


\section{Introduction}

Vitrification of liquid effluents issued from the reprocessing of spent nuclear fuel is considered to be the best solution for long-term immobilization of radionuclides[1]. Minor actinides and fission products in countries which have chosen the reprocessing of spent fuel are confined in borosilicate glasses. Those materials are considered particularly suitable for final disposal in deep, low permeable, geologic formations[2-4]. Work is still in progress to better understand the physical and chemical mechanisms of glass behavior under repository conditions $[5,6]$. Water is considered to be the main cause of glass package corrosion and processes influencing the glass dissolution rate[7-13] must be understood sufficiently well to estimate the performance of nuclear waste glass in its disposal environment over geologic time scales. In this context, isotopic tracers are considered a powerful tool as they are able to trace ion exchanges between the solution and the glass[7, 14-16]. They are used to determine the contribution of the solution and the glass to the isotopic composition of the alteration layers. To this end, recent studies focused on leaching solutions containing amorphous silica highly enriched in ${ }^{29} \mathrm{Si}[7,16]$ in which silicon isotope ratio evolution is monitored at regular time intervals.

For silicon isotope ratio measurements, gas source Isotope Ratio Mass Spectrometry (IRMS)[17] was the predominant technique, but it has been shown that Multi Collection Inductively Coupled Plasma Mass Spectrometry (MC-ICPMS) offers important advantages[18, 19]. The latter technique offers faster analytical protocols (both sample preparation and analysis time), and much smaller samples are required. However, one of the largest drawbacks in mass spectrometry coupled with a plasma source is the occurrence of polyatomic interferences deteriorating isotope ratio accuracy. The presence of a plethora of polyatomic interferences for silicon isotopes has been well documented[18, 20-22], and some of the most prominent are related to ${ }^{14} \mathrm{~N}_{2}{ }^{+},{ }^{14} \mathrm{~N}_{2} \mathrm{H}^{+}$and ${ }^{14} \mathrm{~N}^{16} \mathrm{O}^{+}$, which significantly overlay the ${ }^{28} \mathrm{Si}^{+},{ }^{29} \mathrm{Si}^{+}$and ${ }^{30} \mathrm{Si}^{+}$peaks, respectively. Silicon isotope polyatomic interferences originate from reactions of the sample solvent (i.e. diluted $\mathrm{HNO}_{3}$ ) and entrained atmospheric gases in the plasma, and thus they cannot be removed by chemical purification of the analyzed samples 
In order to overcome this problem and to achieve accurate isotope ratio measurements, $\mathrm{MC}$ ICP-MS with high-resolution capabilities was used[20, 23-25]. In the same context, High Resolution sector field ICP-MS (HR-ICP-MS) was also employed for the determination of silicon concentrations by isotope dilution[26, 27]. An hexapole collision/reaction cell based MC-ICP-MS was also used for silicon isotope ratio measurements in low resolution[28]. However, ${ }^{14} \mathrm{~N}^{16} \mathrm{O}^{+}$interference on ${ }^{30} \mathrm{Si}^{+}$was not resolved, and only ${ }^{29} \mathrm{Si}^{+} /{ }^{28} \mathrm{Si}^{+}$ratios were measured

Silicon isotope ratio determination by quadrupole ICP-MS (ICP-QMS) has not yet been reported to our knowledge. The lack of high resolution capabilities of the ICP-QMS makes silicon isotope ratio analysis quite complex. However, ICP-QMS has been widely employed for total silicon determination in a large variety of sample matrices. The isotope ${ }^{28} \mathrm{Si}^{+}$was mainly used; and to alleviate the problem of polyatomic interferences, Dynamic Reaction Cell (DRC)[29-31], Collision Reaction Interface (CRI)[32, 33], and Octopole Reaction System (ORS) [34, 35] with different gases $\left(\mathrm{NH}_{3}, \mathrm{O}_{2}, \mathrm{CH}_{4}, \mathrm{H}_{2}, \mathrm{He}\right)$ were used.

Recently, Agilent Technologies developed a new ICP-MS using a tandem quadrupole mass filter (ICP-MS/MS)[36, 37]. This new instrument is equipped with an ORS which is placed between the two quadrupole mass filters. When the MS/MS mode is activated, the first quadrupole prevents all off-mass ions from entering the cell, offering superior potential to deal with spectral overlaps in reaction mode

Since the commercialization of the ICP-MS/MS, several scientific works with very interesting analytical results have been published, and a tutorial review is given by Balcaen et al.[38]. With this new instrument, and by using $\mathrm{O}_{2}$ as the reaction gas, total silicon determination was facilitated[39-42] due to a more efficient control of polyatomic interferences compared to a single quadrupole collision/reaction cell-based ICP-QMS. Moreover, with the ICP-MS/MS, more than one isotope can be used for total silicon determination; Amais et al.[40] investigated the potential use of ${ }^{28} \mathrm{Si}^{16} \mathrm{O}^{+}$and ${ }^{29} \mathrm{Si}^{16} \mathrm{O}^{+}$ion species, and Aureli et al.[41] successfully used the three silicon isotopes for silicon content determination of silica nanoparticles. In both cases, calibration curves of the respective silicon isotopes were used supposing silicon natural isotope abundance in samples and standard solutions. 
130

However, although ICP-MS/MS was already used for isotope ratio measurements[37, 43-48], silicon isotope ratio determination has not yet been reported with this technique.

The main objective of this work is to explore the potential of the tandem quadrupole ICP for silicon isotope ratio determination for alteration studies of nuclear glasses. In the present study, we report a novel analytical method which takes into account a number of key settings for accurate silicon isotope ratio analysis like, polyatomic interferences, detector dead time, integration time, number of sweeps, wait time offset, memory blank and instrumental mass fractionation. For the validation of the method, a series of reference solutions with different ${ }^{29} \mathrm{Si}$ enrichment levels were used. The detailed analytical development of the method is presented below.

\section{Experimental}

\subsection{Instrumentation}

The Agilent 8800 ICP-MS/MS (Agilent Technologies, Tokyo, Japan) used in this work has recently been installed at the LT2S laboratory of the Institut de Radioprotection et de Sûreté Nucléaire (IRSN). $\mathrm{O}_{2}$ was used as the reaction gas in the ORS, and silicon isotope ratio measurements were performed in mass shift mode $\left({ }^{\mathrm{x}} \mathrm{Si}^{16} \mathrm{O}_{2}{ }^{+}\right)$. The $\mathrm{O}_{2}$ was introduced through the $4^{\text {th }}$ inlet line. A Peltier-cooled $\left(2^{\circ} \mathrm{C}\right)$ Scott-type spray chamber with a PFA nebulizer $(0.1$ $\mathrm{mL} \min ^{-1}$, ESI, USA) was used as the introduction system. In order to avoid discrete noise components caused by rotation of the peristaltic pump, the self-aspiration mode was used for the sample introduction to the ICP-MS/MS. All of the experimental parameters were optimized daily with a pure silicon test solution $\left(100 \mathrm{ng} \mathrm{g}^{-1}\right)$ in order to obtain the optimum signal-to-background ratio of $\mathrm{m} / \mathrm{z}=60$. Typical sensitivity and stability (Relative Standard Deviation, \%RSD) values measured for $5 \mathrm{~min}$ at $\mathrm{m} / \mathrm{z}=60$ are $\sim 8 \times 10^{5}$ counts per second (cps) / ppm ( $\mu \mathrm{g} \mathrm{g}^{-1}$ ) and $\sim 0.9 \%$, respectively (1 sigma). Before each analytical session, a peak center mass calibration at $\mathrm{m} / \mathrm{z}=60$ (for the quadrupole mass filter after the ORS) was performed. It should be noted that peak center calibration is crucial for high order reaction product ions[49]. For all isotope measurements, the pulse counting mode was ensured. Typical instrumental settings and measurement parameters used throughout the experiments are summarized in Table 1. 


\subsection{Samples and reagents}

Two silicas were used for the preparation of reference solutions and for silicon isotope ratio measurements: i) the Chemgas silica material, highly enriched in ${ }^{29} \mathrm{Si}\left({ }^{28} \mathrm{Si}<0.01 \%,{ }^{29} \mathrm{Si}=\right.$ $99.4 \%,{ }^{30} \mathrm{Si}=0.6 \%$, with ${ }^{29} \mathrm{Si} /{ }^{30} \mathrm{Si}=165.7(8)$ and, ii) the standard reference material IRMM-018a[50] $\left({ }^{28} \mathrm{Si}=92.22036 \%,{ }^{29} \mathrm{Si}=4.68730 \%,{ }^{30} \mathrm{Si}=3.09234 \%\right)$, which for this work represents the natural silicon isotope abundance. The ${ }^{29} \mathrm{Si} /{ }^{28} \mathrm{Si}$ and ${ }^{30} \mathrm{Si} /{ }^{28} \mathrm{Si}$ isotope ratio values of IRMM-018a are equal to $0.0508272(40)$ and $0.0335320(42)$, respectively. For silica digestion, the alkali fusion method was used with $\mathrm{KOH}$ (Suprapur) flux and nickel crucibles. All dilutions were performed with $0.5 \mathrm{M}\left(\mathrm{mol} \mathrm{L}^{-1}\right) \mathrm{HNO}_{3}$ obtained from Ultrapur $(60 \%)$ nitric acid and de-ionized water (18.2 M $\Omega . c m$ Milli Q system, Millipore, USA). The same acid was used as the blank solution and also for the instrument-washing procedure between standards and samples. Sample purification was performed using BioRad AG50 X-12 (200400 mesh) cation exchange resin. For instrument-tuning and oxygen flow rate optimization in the ORS, a solution of $100 \mathrm{ng} \mathrm{g}^{-1}$ of VWR pure silicon solution was used. For all measurements, Ultrapur $\mathrm{O}_{2}$ gas 5.2 quality (99.9992\% purity) was injected in the ORS.

\subsection{Sample preparation}

Around $10 \mathrm{mg}$ of Chemgas and $200 \mathrm{mg}$ of IRMM-018a were mixed with $\mathrm{KOH}$ (Suprapur) and melted at $600^{\circ} \mathrm{C}$. The proportion of the mixture between the silica powder and the $\mathrm{KOH}$ flux used in this work is $\mathrm{mSiO}_{2} / \mathrm{mKOH} \sim 1 / 10$. Potassium hydroxide was preferred over other fluxes such as lithium metaborate and alkaline carbonates because it provides the simplest composition and is easy to eliminate with ion-exchange resin. After alkali fusion, deionized water and diluted $\mathrm{HNO}_{3}(0.5 \mathrm{M})$ was added into the digested materials in order to yield final solution concentrations of $100 \mathrm{ppm}$ and $200 \mathrm{ppm}$ for the Chemgas and the IRMM018a, respectively. The solutions are then stored in chemically inert PTFE vessels. 
181 Five reference solutions with different ${ }^{29} \mathrm{Si}$ enrichment were fabricated by gravimetric mixing of the Chemgas and the IRMM-018a solutions. Values of the reference solutions are presented in table 2 . The $\delta^{29} \mathrm{Si}\left(\delta^{29} \mathrm{Si}=\left[\left({ }^{29} \mathrm{Si} /{ }^{28} \mathrm{Si}\right)_{\text {sample }} /\left({ }^{29} \mathrm{Si} /{ }^{28} \mathrm{Si}\right)_{\text {IRMM }-018 \mathrm{a}}-1\right] \times 1000\right)$ of the mixing solutions was adjusted roughly to $10 \%, 30 \%, 50 \%, 70 \%$ and $100 \%$. This isotope composition of the reference solutions was chosen because of the same order of magnitude with the silicon isotope ratio variation, which is observed for alteration studies of nuclear glasses[15].

$\delta^{30} \mathrm{Si}$ in the mixing solutions is lower than $0.1 \%$. Isotope ratio uncertainties of the reference solutions were calculated by using the binary mixing equation and by propagating uncertainties of the isotope ratios, of the weights of the solutions as well as of their concentrations. Uncertainty propagation was performed using Monte Carlo simulations.

Before silicon isotope ratio analysis, reference solutions and the IRMM-018a were purified using BioRad AG50 X-12 (200-400 mesh) cation exchange resin, as described in detail by Georg et al[23].

\section{Results and discussion}

\subsection{Mass-shift method for interference-free silicon isotope detection}

As previously mentioned, accurate silicon isotope measurements by plasma source spectrometers is hampered by the presence of polyatomic interferences. As for this work, since diluted $\mathrm{HNO}_{3}(0.5 \mathrm{M})$ is the matrix of standards and samples, the generated major polyatomic interferences will contain $\mathrm{N}, \mathrm{O}$ and $\mathrm{H}$. A list of the major potential silicon interferences (after Engström et al.[20]) is presented in table 3. In order to overcome this problem, oxygen was chosen as the reaction gas in the ORS. The reaction of $\mathrm{Si}^{+}$with $\mathrm{O}_{2}$ is an O-atom transfer reaction $\left(\mathrm{Si}^{+}+\mathrm{O}_{2} \rightarrow \mathrm{SiO}^{+}+\mathrm{O}\right)$ and is slightly endothermic[51]. Typically endothermic reactions do not occur spontaneously. However, the plasma source and collisional processes in the cell provide additional energy, which promotes the reaction, enabling the $\mathrm{O}_{2}$ mass-shift method to be applied. 

216

In the mass-shift mode, the first quadrupole (Q1) works as a unit mass filter allowing only ions with $\mathrm{m} / \mathrm{z}=28,29$ and 30 entering the ORS to react with $\mathrm{O}_{2}$. The second quadrupole (Q2) selects ions with $\mathrm{m} / \mathrm{z}=44,45$ and 46 , corresponding to the ions of ${ }^{\mathrm{x}} \mathrm{Si}^{16} \mathrm{O}^{+}$. The oxygen 212 flow in the ORS was optimized by controlling both the signal intensity and the signal-to213 background ratio at $\mathrm{m} / \mathrm{z}=44$, and the optimum flow was found at $0.26 \mathrm{~mL} \mathrm{~min}^{-1}$.

214 In order to investigate if $\mathrm{m} / \mathrm{z}=44,45$ and 46 are free of polyatomic interferences, $0.5 \mathrm{M}$ $215 \mathrm{HNO}_{3}$ blank solution was measured, and count rate ratios $\left(\mathrm{cps}_{45} / \mathrm{cps}_{44}, \mathrm{cps}_{46} / \mathrm{cps}_{44}\right)$ were reported in a three isotope plot and compared to the Exponential Mass Fractionation Law (EMFL, Fig. 1). The EMFL expresses the kinetic isotope fractionation[52] and was used as an indicator of data quality as unresolved interferences should cause ratios to be shifted away from the EMFL. For the calculation of the EMFL, the IRMM-018a reference values were used. Typical count rates for $\mathrm{cps}_{44}, \mathrm{cps}_{45}, \mathrm{cps}_{46}$, in blank solution were found to be $\sim 8.6 \times 10^{3}$, $\sim 6.0 \times 10^{2}$ and $\sim 18.5 \times 10^{3}$, respectively and typical ${ }^{28} \mathrm{Si}^{16} \mathrm{O}^{+}$signal for $100 \mathrm{ng} \mathrm{g}$ of $\mathrm{Si}$ was $\sim 9 \times 10^{5} \mathrm{cps}$.

As can be seen in figure 1 , signal ratios for $\mathrm{HNO}_{3} \quad 0.5 \mathrm{M}$ (green squares) are not in good agreement with the EMFL. If the recorded signals at $\mathrm{m} / \mathrm{z}=44,45$ and 46 were generated only by ${ }^{\mathrm{x}} \mathrm{Si}^{16} \mathrm{O}^{+}$species, $\mathrm{cps}_{45,46} / \mathrm{cps}_{44}$ signal ratios correspond to ${ }^{29,}{ }^{30} \mathrm{Si}^{16} \mathrm{O}^{+} /{ }^{28} \mathrm{Si}^{16} \mathrm{O}^{+}$ ratios, which should be in good agreement with the EMFL (silicon could come from blank impurities and/or instrument silicon-containing materials with natural isotope composition close to the IRMM-018a in both cases). The high $\mathrm{cps}_{46} / \mathrm{cps}_{44}$ ratios relative to the EMFL clearly point to the presence of an important interference at $\mathrm{m} / \mathrm{z}=46 .{ }^{14} \mathrm{~N}^{16} \mathrm{O}^{+}$ion species, formed in the plasma after passing through the first quadrupole filter $(\mathrm{m} / \mathrm{z}=30)$, can react with $\mathrm{O}_{2}$ in the ORS, forming ${ }^{14} \mathrm{~N}^{16} \mathrm{O}_{2}{ }^{+}$which interferes with ${ }^{30} \mathrm{Si}^{16} \mathrm{O}^{+}$at $\mathrm{m} / \mathrm{z}=46$. In order to control the dependence of ${ }^{14} \mathrm{~N}^{16} \mathrm{O}_{2}{ }^{+}$formation against $\mathrm{HNO}_{3}$ concentration, two $\mathrm{HNO}_{3}$ solutions with different concentrations $(0.1 \mathrm{M}$ and $1 \mathrm{M})$ were fabricated from $60 \%$ Ultrapur $\mathrm{HNO}_{3}$, and each solution was measured twice. From figure 1, it is clear that higher $\mathrm{HNO}_{3}$ concentrations favor not only ${ }^{14} \mathrm{~N}^{16} \mathrm{O}_{2}{ }^{+}$formation but also a polyatomic interference at $\mathrm{m} / \mathrm{z}=$ 45. In fact, the same applies to ${ }^{14} \mathrm{~N}_{2}{ }^{1} \mathrm{H}^{+}$and ${ }^{14} \mathrm{~N}^{15} \mathrm{~N}^{+}$ion species $(\mathrm{m} / \mathrm{z}=29)$ which are formed in the plasma and can react with $\mathrm{O}_{2}$ in the ORS, producing ${ }^{14} \mathrm{~N}_{2}{ }^{16} \mathrm{O}^{1} \mathrm{H}^{+}$and ${ }^{14} \mathrm{~N}^{15} \mathrm{~N}^{16} \mathrm{O}^{+}$which interfere with ${ }^{29} \mathrm{Si}^{16} \mathrm{O}^{+}$at $\mathrm{m} / \mathrm{z}=45$. It should be noted that even if ${ }^{14} \mathrm{~N}_{2}{ }^{16} \mathrm{O}^{1} \mathrm{H}^{+},{ }^{14} \mathrm{~N}^{15} \mathrm{~N}^{16} \mathrm{O}^{+}$ and ${ }^{14} \mathrm{~N}^{16} \mathrm{O}_{2}{ }^{+}$are potentially the dominant inferences in this work, to a lesser extent ${ }^{14} \mathrm{~N}_{2}{ }^{+}$and 

265

${ }^{12} \mathrm{C}^{16} \mathrm{O}^{+}(\mathrm{m} / \mathrm{z}=28)$ can react with $\mathrm{O}_{2}$ producing ${ }^{14} \mathrm{~N}_{2}{ }^{16} \mathrm{O}^{+}$and ${ }^{12} \mathrm{C}^{16} \mathrm{O}_{2}{ }^{+}$at $\mathrm{m} / \mathrm{z}=44$, interfering with ${ }^{28} \mathrm{Si}^{16} \mathrm{O}^{+}$ion species at $\mathrm{m} / \mathrm{z}=44$.

The potential formation of polyatomic interferences at $\mathrm{m} / \mathrm{z}=44,45$ and 46 was based on the summary table of polyatomic interferences in ICP-MS after Thomas W. May and Ray H. Wiedmeyer[21].

245 Therefore, on shifting $\mathrm{m} / \mathrm{z}$ from $28,29,30$ to $44,45,46$, we observed that ${ }^{\mathrm{x}} \mathrm{Si}^{16} \mathrm{O}^{+}$ion species 246 are still affected by polyatomic interferences. Thus, this method was not satisfactory for 247 silicon isotope ratio measurements. Moreover, it is worth mentioning that the dependence of 248 the polyatomic interferences with the $\mathrm{HNO}_{3}$ concentration makes their control between 249 different standards and samples complicated and thus their correction quite complex.

250 Another product ion of the silicon reaction with $\mathrm{O}_{2}$ is the ${ }^{\mathrm{x}} \mathrm{SiO}_{2}{ }^{+}$. The potential use of silicon 251 dioxide for silicon isotope ratio measurements was investigated using the mass shift mode. 252 The Q1 was settled at $\mathrm{m} / \mathrm{z}=28,29,30$ and the $\mathrm{Q} 2$ at $\mathrm{m} / \mathrm{z}=60,61,62$. For the oxygen flow 253 optimization in the ORS, the signal intensity and the signal-to-background ratio at $\mathrm{m} / \mathrm{z}=60$ 254 were monitored, and the optimum flow was found at $0.24 \mathrm{~mL} \mathrm{~min}^{-1}$. To control the presence of polyatomic interferences at $\mathrm{m} / \mathrm{z}=60,61$ and 62 , the same procedure described previously was performed. Typical counts rates in blank solution $\left(\mathrm{HNO}_{3} 0.5 \mathrm{M}\right)$ can be found in section 3.4. As can be seen in figure 1 , signal ratios for all $\mathrm{HNO}_{3}$ solutions are in good agreement with the EMFL, and no dependence of signal ratios with $\mathrm{HNO}_{3}$ concentration was observed. This confirms that $\mathrm{m} / \mathrm{z}=60,61,62$ are free of polyatomic interferences, and therefore, ${ }^{\mathrm{x}} \mathrm{SiO}_{2}{ }^{+}$ion species were chosen for silicon isotope ratio determination.

${ }^{28} \mathrm{SiO}_{2}{ }^{+}$was already used for total silicon concentration determination in complex matrices allowing for the improvement of detection limits relative to that obtained for silicon monoxide[39, 42]

264 Isobaric interferences at $\mathrm{m} / \mathrm{z}=44,45,46$ and $\mathrm{m} / \mathrm{z}=60,61,62\left({ }^{44,46} \mathrm{Ca}^{+},{ }^{45} \mathrm{Sc}^{+},{ }^{46} \mathrm{Ti}^{+},{ }^{60,61}\right.$, ${ }^{62} \mathrm{Ni}$ ) as well as their oxides (i.e. ${ }^{44,46} \mathrm{Ca}^{16} \mathrm{O}^{+},{ }^{45} \mathrm{Sc}^{16} \mathrm{O}^{+},{ }^{46} \mathrm{Ti}^{16} \mathrm{O}^{+}$) were not considered because even if traces of these elements were still present in samples and standards after chemical purification, they were discarded from Q1 mass filter. Some of these inferences are presented in table 3 . 
A schematic representation of the operating principle of the tandem mass spectrometer for silicon isotope ratio measurement as well as the added value of the silicon isotope measurement as ${ }^{\mathrm{x}} \mathrm{Si}^{16} \mathrm{O}_{2}{ }^{+}$ion species are shown in figure 2 .

\subsection{Optimization of data acquisition parameters for isotope ratio measurements.}

273 A number of key settings for accurate silicon isotope ratio measurements were tested and 274 optimized. The reliability of the detector dead time (adjusted by the manufacturer at $31.8 \mathrm{~ns}$ ) 275 was controlled using silicon solutions with different concentrations (between $100 \mathrm{ng} \mathrm{g}^{-1}$ and $276700 \mathrm{ng} \mathrm{g}^{-1}$ ). No significant variation of the ${ }^{29,}{ }^{30} \mathrm{Si}^{16} \mathrm{O}_{2}{ }^{+} /{ }^{28} \mathrm{Si}^{16} \mathrm{O}_{2}{ }^{+}$ratios with the silicon 277 concentration was observed, and thus no reevaluation of the detector dead time was needed.

278 The effect of the integration time and the number of sweeps per replicate on the isotope ratio 279 precision was also investigated. The isotope ratio precision was expressed as the Relative 280 Standard Deviation (\%RSD) of the ${ }^{29} \mathrm{Si}^{16} \mathrm{O}_{2}{ }^{+} /{ }^{28} \mathrm{Si}^{16} \mathrm{O}_{2}^{+}$ratio for 10 replicates. For all these 281 tests, a solution of $400 \mathrm{ng} \mathrm{g}^{-1}$ of IRMM-018a was used. This concentration was chosen 282 because it is close to that which was used for reference solution measurements. First, the 283 integration time of the ${ }^{29} \mathrm{Si}^{16} \mathrm{O}_{2}^{+}$was varied and that of ${ }^{28} \mathrm{Si}^{16} \mathrm{O}_{2}{ }^{+}$was kept constant at $1 \mathrm{~s}$. 284 During the optimization tests of the integration time, the number of sweeps was fixed at 1 and 285 for this reason the integration time is the dwell time of the detected ion species.

286 As expected, the increase of the integration time significantly improved the \%RSD of $287{ }^{29} \mathrm{Si}^{16} \mathrm{O}_{2}{ }^{+} /{ }^{28} \mathrm{Si}^{16} \mathrm{O}_{2}{ }^{+}$ratio, and the improvement follows the counting statistics law (Fig. 3a). 288 The counting statistics law is described by the following equation:

291 where $\mathrm{c}_{29}$ and $\mathrm{c}_{28}$ are the total counts (cps $\times$ integration time) for ${ }^{29} \mathrm{Si}^{16} \mathrm{O}_{2}^{+}$and ${ }^{28} \mathrm{Si}^{16} \mathrm{O}_{2}{ }^{+}$ 292 respectively. As can be seen from the counting statistic law (Fig. 3a), integration times higher 293 than $6 \mathrm{~s}$ result in a slight improvement of the \%RSD. For this reason, and in order to keep the 294 total analysis time as low as possible, $6 \mathrm{~s}$ was chosen as the integration time for both ${ }^{29} \mathrm{Si}^{16} \mathrm{O}_{2}{ }^{+}$ 295 and ${ }^{30} \mathrm{Si}^{16} \mathrm{O}_{2}^{+}$as their abundances are similar. In the same context, the increase of the $296{ }^{28} \mathrm{Si}^{16} \mathrm{O}_{2}{ }^{+}$integration time beyond $1 \mathrm{~s}$ does not bring a significant improvement of the \%RSD (figure $3 \mathrm{a}$, dashed lines), and thus, $1 \mathrm{~s}$ was chosen as the integration time for ${ }^{28} \mathrm{Si}^{16} \mathrm{O}_{2}{ }^{+}$. 
298 Then the integration times were kept constant $\left(6 \mathrm{~s}\right.$ for ${ }^{29,}{ }^{30} \mathrm{Si}^{16} \mathrm{O}_{2}{ }^{+}$and $1 \mathrm{~s}$ for ${ }^{28} \mathrm{Si}^{16} \mathrm{O}_{2}{ }^{+}$), and the number of sweeps per replicate was varied. The role of the sweeps is to rapidly scan the different isotopes (ion species) in order to approximate a simultaneous measurement. As can be seen in figure $3 b$, the number of sweeps does not significantly influence the ratio $\% R S D$, and 20 sweeps per replicate was chosen for silicon isotope ratio measurements. With this number of sweeps, the dwell time of ${ }^{29,}{ }^{30} \mathrm{Si}^{16} \mathrm{O}_{2}{ }^{+}$and ${ }^{28} \mathrm{Si}^{16} \mathrm{O}_{2}{ }^{+}$was $0.3 \mathrm{~s}$ and $0.05 \mathrm{~s}$ respectively.

Particular attention was paid to the optimization of the Wait Time Offset (WTO). The WTO is an additional wait time to the Q1 settling time, compensating for the slowdown of the ions in the ORS and giving the system time to arrive at steady state conditions[47, 53]. Different values of WTO were tested; and as can be seen in figure 4, no significant influence on the ${ }^{29}$, ${ }^{30} \mathrm{Si}^{16} \mathrm{O}_{2}{ }^{+} /{ }^{28} \mathrm{Si}^{16} \mathrm{O}_{2}{ }^{+}$ratio was noticed. A WTO of $3 \mathrm{~ms}$ was selected for this work.

No replicates were performed for the measurements which were used for the optimization of the data acquisition parameters and ratio uncertainties presented in figure 4 were calculated following the next equation: $2 \times \mathrm{SD} / \sqrt{\mathrm{n}}$, were $S D$ is the Standard Deviation and $n$ the number of replicates per measurement, in this case $n=10$.

\subsection{Optimization of the abundance sensitivity}

316 Several measurements of the IRMM-018a standard solution (400 $\mathrm{ng} \mathrm{g}^{-1}$ ) were performed, and 317 silicon dioxide ratios were reported in a three-isotope plot (Fig. 5, blue dots). As can be seen, 318 the data are significantly shifted away from the EMFL. As silicon measurement in its dioxide 319 form is not suffering from polyatomic interferences, the influence of the abundance sensitivity 320 of the Q1 mass filter was examined to explain this shift.

321 Abundance sensitivity is one of the most important figures of merit in a mass spectrometer 322 system for precise isotope determination. It describes the signal contribution of the peak tail 323 of a high-abundance isotope with mass $M$ at neighboring masses $(M \pm 1, M \pm 2$, etc.). 324 Although abundance sensitivity is influenced by several factors (design of the quadrupole 325 rods[54], frequency of the power supply, etc.), kinetic energy of the ions, as they enter the quadrupole, operating vacuum[55] and peak resolution, has the biggest impact. 

340

Although sequential transmission of silicon isotopes into the ORS prevents spectral overlaps due to the presence of different oxygen isotopes[44] (i.e. ${ }^{28} \mathrm{Si}^{16} \mathrm{O}^{18} \mathrm{O}^{+},{ }^{30} \mathrm{Si}^{16} \mathrm{O}^{16} \mathrm{O}^{+}$), accurate silicon isotope ratio measurement can be hampered by the contribution of ${ }^{28} \mathrm{Si}^{+}$peak tailing on ${ }^{29} \mathrm{Si}^{+}$and ${ }^{30} \mathrm{Si}^{+}$(at $\mathrm{M}+1$ and $\mathrm{M}+2$ ). During ${ }^{29} \mathrm{Si}^{+}$and ${ }^{30} \mathrm{Si}^{+}$ion transmission through Q1mass filter, a small amount of ${ }^{28} \mathrm{Si}^{+}$enters the ORS and, ${ }^{28} \mathrm{Si}^{16} \mathrm{O}^{17} \mathrm{O}^{+}(\mathrm{m} / \mathrm{z}=61)$ interferes with ${ }^{29} \mathrm{Si}^{16} \mathrm{O}^{16} \mathrm{O}^{+}(\mathrm{m} / \mathrm{z}=61)$ shifting the data to the right and, ${ }^{28} \mathrm{Si}^{16} \mathrm{O}^{18} \mathrm{O}^{+}(\mathrm{m} / \mathrm{z}=62)$ and ${ }^{28} \mathrm{Si}^{17} \mathrm{O}^{17} \mathrm{O}^{+}(\mathrm{m} / \mathrm{z}=62)$ interfere with ${ }^{30} \mathrm{Si}^{16} \mathrm{O}^{16} \mathrm{O}^{+}(\mathrm{m} / \mathrm{z}=62)$ shifting the data upwards (Fig.5). 335 Therefore, ${ }^{28} \mathrm{Si}^{+}$peak tail in high masses can explain the shift of the ratio data away from the 336 EMFL.

337 When the ORS is pressurized with $\mathrm{O}_{2}$, the analyzer pressure increases from $\sim 2.4 \times 10^{-4} \mathrm{~Pa}$ (no 338 gas in the ORS) to $\sim 6.3 \times 10^{-4} \mathrm{~Pa}$ (with $0.24 \mathrm{~mL} \mathrm{~min}^{-1}$ of $\mathrm{O}_{2}$ in the ORS). It is well accepted 339 that a lower vacuum in the analyzer can lead to more collisions between gas molecules and ions, resulting in a higher spread in kinetic energy of the ions and therefore more of a tail mainly at the low mass side of the main peak[55]. As our aim was to work in optimum condition of signal-to-background ratio, the $\mathrm{O}_{2}$ flux was maintained at the same value and, no investigations were carried about the operating vacuum of the instrument.

Parameters influencing the peak resolution and the kinetic energy of the ions entering the quadrupole were explored and optimized. The Q1 Mass Offset, Q1 Mass Gain and Extract 2, were settled in order to minimize ${ }^{28} \mathrm{Si}^{+}$peak tailing contribution on ${ }^{29} \mathrm{Si}^{+}$and ${ }^{30} \mathrm{Si}^{+}$. With the first two parameters, the peak resolution was improved from $\sim 0.8 \mathrm{amu}$ to $\sim 0.57 \mathrm{amu}$ (at $10 \%$ of peak high). The last parameter allowed the reducing of the ion kinetic energy, which leads to an increase in the residence time of ions in the quadrupole mass analyzer and results in improved mass separation. After parameter optimization, data fit well with the EMFL (Fig. 5, red dots), confirming that Q1 abundance sensitivity was efficiently improved. However, it should be noted that peak tailing improvement was accompanied by a sacrifice in sensitivity of about $15 \%$. Sensitivity performance, presented in section 2.1 (Instrumentation), has taken into account abundance sensitivity optimization. 


\subsection{Memory blank and instrumental mass fractionation}

361 For memory blank, a washing procedure to reduce signal intensities was applied after every 362 sample or standard. This procedure included a short pre-wash of the auto-sampler probe for $10 \mathrm{~s}$ with $0.5 \mathrm{M} \mathrm{HNO}_{3}$ and a wash for $2 \mathrm{~min}$ with the same acid. After washing, silicon dioxide intensities were measured for $0.5 \mathrm{M} \mathrm{HNO}_{3}$ blank solution and then corrected to sample and standard measurements. Typical intensities for ${ }^{28,}{ }^{29,}{ }^{30} \mathrm{Si}^{16} \mathrm{O}_{2}{ }^{+}$in blank solution were found to be $\sim 800 \mathrm{cps}, \sim 40 \mathrm{cps}$ and $\sim 30 \mathrm{cps}$, respectively. The wash procedure effectively reduces signal intensities to the original blank values. Procedural blank intensities were found to be at the same level with that of $\mathrm{HNO}_{3}$ blank solution.

The sample-standard bracketing procedure (standard solution (IRMM-018a) - sample $\left({ }^{29} \mathrm{Si}\right.$ enriched reference solutions) - standard solution (IRMM-018a)) was adopted to correct for instrumental mass fractionation. To do this, the exponential mass fractionation law[56] was used:

$$
\mathrm{R}_{\text {true }}=\mathrm{R}_{\text {meas }}\left(\mathrm{m}_{1} / \mathrm{m}_{2}\right)^{\beta}
$$

where $R_{\text {true }}$ and $R_{\text {meas }}$ are the true and measured isotope ratios for isotopes 1 and 2, with $m_{1}$ and $m_{2}$ being their respective atomic masses, and $\beta$, the mass fractionation factor. The $\beta$ factors were calculated for both ${ }^{29} \mathrm{Si} /{ }^{28} \mathrm{Si}$ and ${ }^{30} \mathrm{Si} /{ }^{28} \mathrm{Si}$ ratios (in ${ }^{\mathrm{x}} \mathrm{SiO}_{2}{ }^{+}$form) of the IRMM018a standard solution $\left(\beta_{29 / 28}, \beta_{30 / 28}\right)$. These factors were used for the correction of the isotope fractionation for the respective ratios $\left({ }^{29} \mathrm{Si} /{ }^{28} \mathrm{Si},{ }^{30} \mathrm{Si} /{ }^{28} \mathrm{Si}\right)$ of the reference solutions. 


\subsection{Isotope composition determination of ${ }^{29} \mathrm{Si}$-enriched reference solutions}

The developed method described above was applied to measure isotope composition in a series of reference solutions with different ${ }^{29} \mathrm{Si}$ enrichment (Table 2). Silicon isotope ratio measurements were found to be in good agreement with the values of the reference solutions (zeta-score $<2$, according to ISO 13528[57]) that allowed for the validation of our method (Fig. 6).

393 Each measurement consisted of fifteen consecutive replicates and every solution was 394 measured three times in order to estimate the method repeatability which was calculated as 395 the $\%$ RSD for the three measurements.

396 Isotope ratio uncertainties were calculated for each individual measurement by propagating 397 uncertainties of the mass fractionation factors $\left(\beta_{29 / 28}, \beta_{30 / 28}\right)$ and of the measured silicon ratios 398 (calculated using $2 \times \mathrm{SD} / \sqrt{ } 15$ ). The detailed equation for uncertainty propagation used in this 399 work can be found in Section 5 of the Supplementary Information by Gourgiotis et al.[58]. 400 The method repeatability and the isotope ratio uncertainties were calculated for a coverage 401 factor $k=2$.

402 This method allowed achieving isotope ratio trueness, uncertainty and repeatability at $<0.2 \%$, $403<0.5 \%,<0.6 \%$, respectively. Reference solution repeatability was similar to repeatability 404 obtained for the IRMM-018a $\left(0.2 \%\right.$ and $0.4 \%$ for $\left.{ }^{29,}{ }^{30} \mathrm{Si} /{ }^{28} \mathrm{Si}, \mathrm{n}=16\right)$ during the analytical 405 protocol for the measurement of the reference solutions $(\sim 4 \mathrm{~h})$. These performances are similar 406 to those obtained for silicon isotope measurements by HR-ICP-MS for silicon Isotope 407 Dilution[27]. Average values of, isotope ratios, uncertainties, zeta-score, repeatability and 408 trueness can be found in table 4. 


\subsection{Conclusion}

414 This is the first time where silicon isotope ratio measurements were performed by quadrupole415 based ICP-MS and more specifically by ICP-MS/MS. In order to avoid silicon polyatomic 424 transferred to other application fields like geosciences, i.e. for precise silicon content 425 determination in natural samples by Isotope Dilution (ID). interferences, oxygen was used as the reaction gas in the ORS, and silicon isotope determination was performed in mass-shift mode using $\mathrm{SiO}_{2}{ }^{+}$ion species. A number of key parameters for accurate isotope ratio measurements were carefully evaluated and corrected. With this new method, isotope ratio uncertainties, trueness and repeatability were found to be $<0.5 \%,<0.2 \%$ and $<0.6 \%$, respectively. The method performances meet the requirements for nuclear glasses studies and more generally for investigations of silicate dissolution rates based on isotope doping[59].

We believe that this method can be seen as a valid alternative for HR-ICP-MS and be easily 
[1] C. Poinssot, S. Gin, Long-term Behavior Science: The cornerstone approach for reliably assessing the long-term performance of nuclear waste, Journal of Nuclear Materials, 420 (2012) 182-192.

[2] I.W. Donald, Waste Immobilization in Glass and Ceramic Based Hosts: Radioactive, Toxic and Hazardous Wastes, John Wiley \& Sons Inc., 2010.

[3] M.I. Ojovan, W.E. Lee, New Developments in Glassy Nuclear Wasteforms, Nova Science Publishers Inc., New York2007.

[4] B. Grambow, Nuclear Waste Glasses - How Durable?, Elements, 2 (2006) 357-364.

[5] J.D. Vienna, J.V. Ryan, S. Gin, Y. Inagaki, Current Understanding and Remaining Challenges in Modeling Long-Term Degradation of Borosilicate Nuclear Waste Glasses, International Journal of Applied Glass Science, 4 (2013) 283-294.

[6] S. Gin, A. Abdelouas, L.J. Criscenti, W.L. Ebert, K. Ferrand, T. Geisler, M.T. Harrison, Y. Inagaki, S. Mitsui, K.T. Mueller, J.C. Marra, C.G. Pantano, E.M. Pierce, J.V. Ryan, J.M. Schofield, C.I. Steefel, J.D. Vienna, An international initiative on long-term behavior of high-level nuclear waste glass, Materials Today, 16 (2013) 243-248.

[7] S. Gin, P. Jollivet, M. Fournier, F. Angeli, P. Frugier, T. Charpentier, Origin and consequences of silicate glass passivation by surface layers, Nat Commun, 6 (2015).

[8] S. Gin, P. Frugier, P. Jollivet, F. Bruguier, E. Curti, New Insight into the Residual Rate of Borosilicate Glasses: Effect of S/V and Glass Composition, International Journal of Applied Glass Science, 4 (2013) 371-382.

[9] S. Gin, X. Beaudoux, F. Angéli, C. Jégou, N. Godon, Effect of composition on the short-term and long-term dissolution rates of ten borosilicate glasses of increasing complexity from 3 to 30 oxides, Journal of Non-Crystalline Solids, 358 (2012) 2559-2570.

[10] P. Frugier, S. Gin, Y. Minet, T. Chave, B. Bonin, N. Godon, J.E. Lartigue, P. Jollivet, A. Ayral, L. De Windt, G. Santarini, SON68 nuclear glass dissolution kinetics: Current state of knowledge and basis of the new GRAAL model, Journal of Nuclear Materials, 380 (2008) 8-21.

[11] D. Rebiscoul, A. Van der Lee, F. Rieutord, F. Né, O. Spalla, A. El-Mansouri, P. Frugier, A. Ayral, S. Gin, Morphological evolution of alteration layers formed during nuclear glass alteration: new evidence of a gel as a diffusive barrier, Journal of Nuclear Materials, 326 (2004) 9-18.

[12] K. Ferrand, A. Abdelouas, B. Grambow, Water diffusion in the simulated French nuclear waste glass SON 68 contacting silica rich solutions: Experimental and modeling, Journal of Nuclear Materials, 355 (2006) 54-67.

[13] P. Jollivet, F. Angeli, C. Cailleteau, F. Devreux, P. Frugier, S. Gin, Investigation of gel porosity clogging during glass leaching, Journal of Non-Crystalline Solids, 354 (2008) 4952-4958.

[14] B.P. McGrail, J.P. Icenhower, D.K. Shuh, P. Liu, J.G. Darab, D.R. Baer, S. Thevuthasen, V. Shutthanandan, M.H. Engelhard, C.H. Booth, P. Nachimuthu, The structure of Na2O-Al2O3-SiO2 glass: impact on sodium ion exchange in $\mathrm{H} 2 \mathrm{O}$ and D2O, Journal of Non-Crystalline Solids, 296 (2001) $10-26$

[15] N. Valle, A. Verney-Carron, J. Sterpenich, G. Libourel, E. Deloule, P. Jollivet, Elemental and isotopic (29Si and 180) tracing of glass alteration mechanisms, Geochimica et Cosmochimica Acta, 74 (2010) 3412-3431.

[16] S. Gin, P. Jollivet, M. Fournier, C. Berthon, Z. Wang, A. Mitroshkov, Z. Zhu, J.V. Ryan, The fate of silicon during glass corrosion under alkaline conditions: A mechanistic and kinetic study with the International Simple Glass, Geochimica et Cosmochimica Acta, 151 (2015) 68-85.

[17] M.A. Brzezinski, J.L. Jones, C.P. Beucher, M.S. Demarest, H.L. Berg, Automated Determination of Silicon Isotope Natural Abundance by the Acid Decomposition of Cesium Hexafluosilicate, Analytical Chemistry, 78 (2006) 6109-6114. 
[18] D. Cardinal, L.Y. Alleman, J. de Jong, K. Ziegler, L. Andre, Isotopic composition of silicon measured by multicollector plasma source mass spectrometry in dry plasma mode, Journal of Analytical Atomic Spectrometry, 18 (2003) 213-218.

[19] C.L. De La Rocha, Measurement of silicon stable isotope natural abundances via multicollector inductively coupled plasma mass spectrometry (MC-ICP-MS), Geochemistry, Geophysics, Geosystems, 3 (2002) 1-8.

[20] E. Engström, I. Rodushkin, D.C. Baxter, B. Öhlander, Chromatographic Purification for the Determination of Dissolved Silicon Isotopic Compositions in Natural Waters by High-Resolution Multicollector Inductively Coupled Plasma Mass Spectrometry, Analytical Chemistry, 78 (2006) 250257.

[21] T.W. May, R.H. Wiedmeyer, A Table of Polyatomic Interferences in ICP-MS, Atomic Spectroscopy, 19 (1998) 150-155.

[22] Y. Takaku, K. Masuda, T. Takahashi, T. Shimamura, Determination of trace silicon in ultra-highpurity water by inductively coupled plasma mass spectrometry, Journal of Analytical Atomic Spectrometry, 9 (1994) 1385-1387.

[23] R.B. Georg, B.C. Reynolds, M. Frank, A.N. Halliday, New sample preparation techniques for the determination of Si isotopic compositions using MC-ICPMS, Chemical Geology, 235 (2006) 95-104.

[24] K. Abraham, S. Opfergelt, F. Fripiat, A.-J. Cavagna, J.T.M. De Jong, S.F. Foley, L. André, D. Cardinal, $830 \mathrm{Si}$ and $\delta 29 \mathrm{Si}$ Determinations on USGS BHVO-1 and BHVO-2 Reference Materials with a New Configuration on a Nu Plasma Multi-Collector ICP-MS, Geostandards and Geoanalytical Research, 32 (2008) 193-202.

[25] P.S. Savage, F. Moynier, Silicon isotopic variation in enstatite meteorites: Clues to their origin and Earth-forming material, Earth and Planetary Science Letters, 361 (2013) 487-496.

[26] P. Klemens, K.G. Heumann, Development of an ICP-HRIDMS method for accurate determination of traces of silicon in biological and clinical samples, Fresenius' Journal of Analytical Chemistry, 371 (2001) 758-763.

[27] F. Fripiat, R. Corvaisier, J. Navez, M. Elskens, V. Schoemann, K. Leblanc, L. André, D. Cardinal, Measuring production-dissolution rates of marine biogenic silica by 30Si-isotope dilution using a high-resolution sector field inductively coupled plasma mass spectrometer, Limnology and Oceanography: Methods, 7 (2009) 470-478.

[28] X. Sun, P. Andersson, M. Land, C. Humborg, C.-M. Morth, Stable silicon isotope analysis on nanomole quantities using MC-ICP-MS with a hexapole gas-collision cell, Journal of Analytical Atomic Spectrometry, 25 (2010) 156-162.

[29] H.-t. Liu, S.-J. Jiang, Dynamic reaction cell inductively coupled plasma mass spectrometry for determination of silicon in steel, Spectrochimica Acta Part B: Atomic Spectroscopy, 58 (2003) 153157.

[30] C.-H. Yang, S.-J. Jiang, Determination of B, Si, P and S in steels by inductively coupled plasma quadrupole mass spectrometry with dynamic reaction cell, Spectrochimica Acta Part B: Atomic Spectroscopy, 59 (2004) 1389-1394.

[31] F. Aureli, M. D'Amato, B. De Berardis, A. Raggi, A.C. Turco, F. Cubadda, Investigating agglomeration and dissolution of silica nanoparticles in aqueous suspensions by dynamic reaction cell inductively coupled plasma-mass spectrometry in time resolved mode, Journal of Analytical Atomic Spectrometry, 27 (2012) 1540-1548.

[32] D.R. Neves, R.S. Amais, J.A. Nóbrega, J.A.G. Neto, Assessment of Polyatomic Interferences Elimination Using a Collision Reaction Interface (CRI) for Inorganic Analysis of Fuel Ethanol by ICPQMS, Analytical Letters, 45 (2012) 1111-1121.

[33] G.L. Donati, R.S. Amais, J.A. Nobrega, Tungsten coil electrothermal matrix decomposition and sample vaporization to determine $\mathrm{P}$ and $\mathrm{Si}$ in biodiesel by inductively coupled plasma mass spectrometry, Journal of Analytical Atomic Spectrometry, 28 (2013) 280-287.

[34] J. Heroult, V. Nischwitz, D. Bartczak, H. Goenaga-Infante, The potential of asymmetric flow fieldflow fractionation hyphenated to multiple detectors for the quantification and size estimation of silica nanoparticles in a food matrix, Analytical and Bioanalytical Chemistry, 406 (2014) 3919-3927. 
[35] G.D. Woods, F.I. Fryer, Direct elemental analysis of biodiesel by inductively coupled plasmamass spectrometry, Analytical and Bioanalytical Chemistry, 389 (2007) 753-761.

[36] S.D. Fernández, N. Sugishama, J.R. Encinar, A. Sanz-Medel, Triple Quad ICPMS (ICPQQQ) as a New Tool for Absolute Quantitative Proteomics and Phosphoproteomics, Analytical Chemistry, 84 (2012) 5851-5857.

[37] L. Balcaen, G. Woods, M. Resano, F. Vanhaecke, Accurate determination of S in organic matrices using isotope dilution ICP-MS/MS, Journal of Analytical Atomic Spectrometry, 28 (2013) 33-39.

[38] L. Balcaen, E. Bolea-Fernandez, M. Resano, F. Vanhaecke, Inductively coupled plasma - Tandem mass spectrometry (ICP-MS/MS): A powerful and universal tool for the interference-free determination of (ultra)trace elements - A tutorial review, Analytica Chimica Acta, 894 (2015) 7-19. [39] Trace level analysis of sulfur, phosphorus, silicon and chlorine in NMP using the Agilent 8800 triple Quadrupole ICP-MS, Application note: 5991-2303EN, 2013.

[40] R.S. Amais, C.D.B. Amaral, L.L. Fialho, D. Schiavo, J.A. Nobrega, Determination of P, S and Si in biodiesel, diesel and lubricating oil using ICP-MS/MS, Analytical Methods, 6 (2014) 4516-4520.

[41] F. Aureli, M. D'Amato, A. Raggi, F. Cubadda, Quantitative characterization of silica nanoparticles by asymmetric flow field flow fractionation coupled with online multiangle light scattering and ICPMS/MS detection, Journal of Analytical Atomic Spectrometry, 30 (2015) 1266-1273.

[42] A. Virgilio, R.S. Amais, D. Schiavo, J.A. Nóbrega, Dilute-and-Shoot Procedure for Determination of As, $\mathrm{Cr}, \mathrm{P}, \mathrm{Pb}, \mathrm{Si}$, and $\mathrm{V}$ in Ethanol Fuel by Inductively Coupled Plasma Tandem Mass Spectrometry, Energy \& Fuels, 29 (2015) 4339-4344.

[43] T. Ohno, Y. Muramatsu, Y. Shikamori, C. Toyama, N. Okabe, H. Matsuzaki, Determination of ultratrace 129 I in soil samples by Triple Quadrupole ICP-MS and its application to Fukushima soil samples, Journal of Analytical Atomic Spectrometry, 28 (2013) 1283-1287.

[44] M. Tanimizu, N. Sugiyama, E. Ponzevera, G. Bayon, Determination of ultra-low 236U/238U isotope ratios by tandem quadrupole ICP-MS/MS, Journal of Analytical Atomic Spectrometry, 28 (2013) 1372-1376.

[45] T. Ohno, Y. Muramatsu, Determination of radioactive cesium isotope ratios by triple quadrupole ICP-MS and its application to rainwater following the Fukushima Daiichi Nuclear Power Plant accident, Journal of Analytical Atomic Spectrometry, 29 (2014) 347-351.

[46] J. Zheng, W. Bu, K. Tagami, Y. Shikamori, K. Nakano, S. Uchida, N. Ishii, Determination of 135Cs and $135 \mathrm{Cs} / 137 \mathrm{Cs}$ Atomic Ratio in Environmental Samples by Combining Ammonium Molybdophosphate (AMP)-Selective Cs Adsorption and Ion-Exchange Chromatographic Separation to Triple-Quadrupole Inductively Coupled Plasma-Mass Spectrometry, Analytical Chemistry, 86 (2014) 7103-7110.

[47] E. Bolea-Fernandez, L. Balcaen, M. Resano, F. Vanhaecke, Tandem ICP-mass spectrometry for Sr isotopic analysis without prior $\mathrm{Rb} / \mathrm{Sr}$ separation, Journal of Analytical Atomic Spectrometry, 31 (2016) 303-310.

[48] E. Bolea-Fernandez, S.J.M. Van Malderen, L. Balcaen, M. Resano, F. Vanhaecke, Laser ablationtandem ICP-mass spectrometry (LA-ICP-MS/MS) for direct Sr isotopic analysis of solid samples with high Rb/Sr ratios, Journal of Analytical Atomic Spectrometry, 31 (2016) 464-472.

[49] L. Balcaen, E. Bolea-Fernandez, M. Resano, F. Vanhaecke, Accurate determination of ultra-trace levels of Ti in blood serum using ICP-MS/MS, Analytica Chimica Acta, 809 (2014) 1-8.

[50] S. Valkiers, T. Ding, M. Inkret, K. Ruße, P. Taylor, Silicon isotope amount ratios and molar masses for two silicon isotope reference materials: IRMM-018a and NBS28, International Journal of Mass Spectrometry, 242 (2005) 319-321.

[51] Agilent 8800 Triple Quadrupole ICP-MS, Understanding oxygen reaction mode in ICP-MS/MS, Application note: 5991-1708EN, 2012.

[52] E.D. Young, A. Galy, H. Nagahara, Kinetic and equilibrium mass-dependent isotope fractionation laws in nature and their geochemical and cosmochemical significance, Geochimica et Cosmochimica Acta, 66 (2002) 1095-1104.

[53] Agilent 8800 Triple Quadrupole ICP-MS, Hardware Maintenance Manual, Agilent Technologies pp. 134-135. 
591 [54] K. Blaum, C. Geppert, P. Müller, W. Nörtershäuser, E.W. Otten, A. Schmitt, N. Trautmann, K. Wendt, B.A. Bushaw, Properties and performance of a quadrupole mass filter used for resonance [55] C.-C. Shen, R. Lawrence Edwards, H. Cheng, J.A. Dorale, R.B. Thomas, S. Bradley Moran, S.E. Weinstein, H.N. Edmonds, Uranium and thorium isotopic and concentration measurements by magnetic sector inductively coupled plasma mass spectrometry, Chemical Geology, 185 (2002) 165178.

[56] W.A. Russell, D.A. Papanastassiou, T.A. Tombrello, Ca isotope fractionation on the Earth and other solar system materials, Geochimica et Cosmochimica Acta, 42 (1978) 1075-1090.

[57] Statistical methods for use in proficiency testing by interlaboratory comparisons, ISO 13528, (2015).

[58] A. Gourgiotis, S. Berail, P. Louvat, H. Isnard, J. Moureau, A. Nonell, G. Manhes, J.-L. Birck, J. Gaillardet, C. Pecheyran, F. Chartier, O.F.X. Donard, Method for isotope ratio drift correction by internal amplifier signal synchronization in MC-ICPMS transient signals, Journal of Analytical Atomic Spectrometry, 29 (2014) 1607-1617.

[59] C. Zhu, Z. Liu, A. Schaefer, C. Wang, G. Zhang, C. Gruber, J. Ganor, R.B. Georg, Geochemistry of the Earth's surface GES-10 Paris France, 18-23 August, 2014.Silicon Isotopes as a New Method of Measuring Silicate Mineral Reaction Rates at Ambient Temperature, Procedia Earth and Planetary Science, 10 (2014) 189-193. 


\begin{tabular}{|c|c|}
\hline \multicolumn{2}{|l|}{ Tables } \\
\hline \multicolumn{2}{|l|}{ ICP-MS/MS } \\
\hline \multicolumn{2}{|l|}{ Sample Introduction System } \\
\hline Nebulizer & PFA Micro-Concentric (ESI) \\
\hline Spray chamber & Scott (quartz) \\
\hline Torch & One-piece (quartz) \\
\hline Sample gas $\left(\mathrm{L} \min ^{-1}\right)$ & 0.88 \\
\hline Ar makeup gas $\left(\mathrm{L} \min ^{-1}\right)$ & 0.36 \\
\hline Liquid uptake $\left(\mu \mathrm{L} \min ^{-1}\right)$ & $\sim 150$ \\
\hline \multicolumn{2}{|l|}{$I C P-M S M S$ conditions } \\
\hline RF power (W) & 1550 \\
\hline Plasma gas flow rate $\left(\mathrm{L} \mathrm{min}^{-1}\right)$ & 15 \\
\hline Auxiliary flow rate $\left(\mathrm{L} \mathrm{min}^{-1}\right)$ & 0.9 \\
\hline Extract 1 and $2(V)$ & $-3,-195$ \\
\hline Q1 and 2 Mass Gain & 152,126 \\
\hline Q1 and 2 Mass Offset & 131,128 \\
\hline $\mathrm{O}_{2}$ reaction gas flow rate $\left(\mathrm{mL} \mathrm{min}^{-1}\right)$ & 0.24 \\
\hline Sensitivity on ${ }^{28} \mathrm{Si}^{16} \mathrm{O}_{2}{ }^{+}\left(\mathrm{cps} \mathrm{ppm}{ }^{-1}\right)$ & $\sim 8 \times 10^{5}$ \\
\hline Signal on ${ }^{28} \mathrm{Si}^{16} \mathrm{O}_{2}{ }^{+}$for $\mathrm{HNO}_{3} 0.5 \mathrm{M}$ (cps) & $\sim 800$ \\
\hline \multicolumn{2}{|l|}{ Acquisition parameters } \\
\hline Peak shape (points) & 1 \\
\hline Integration time for ${ }^{28,29,30} \mathrm{Si}^{16} \mathrm{O}_{2}^{+}(\mathrm{s})$ & $1,6,6$ \\
\hline Number of sweeps per replicate & 20 \\
\hline Number of replicates per sample & 15 \\
\hline
\end{tabular}

628 Table 1. ICP-MS/MS operating conditions 


\begin{tabular}{llll}
\hline & Isotopes/molecules & \multicolumn{2}{l}{ Interferences } \\
\cline { 3 - 4 } $\mathrm{m} / \mathrm{z}$ & of interest & Isobaric & Polyatomic \\
\hline 28 & ${ }^{28} \mathrm{Si}^{+}$ & ${ }^{14} \mathrm{~N}_{2}{ }^{+},{ }^{12} \mathrm{C}^{16} \mathrm{O}^{+}$ \\
29 & ${ }^{29} \mathrm{Si}^{+}$ & & ${ }^{14} \mathrm{~N}_{2}{ }^{1} \mathrm{H}^{+}$ \\
30 & ${ }^{30} \mathrm{Si}^{+}$ & ${ }^{14} \mathrm{~N}^{16} \mathrm{O}^{+}$ \\
44 & ${ }^{28} \mathrm{Si}^{16} \mathrm{O}^{+}$ & ${ }^{44} \mathrm{Ca}^{+}$ & ${ }^{14} \mathrm{~N}_{2}{ }^{16} \mathrm{O}^{+},{ }^{12} \mathrm{C}^{16} \mathrm{O}_{2}{ }^{+}$ \\
45 & ${ }^{29} \mathrm{Si}^{16} \mathrm{O}^{+}$ & ${ }^{45} \mathrm{Sc}^{+}$ & ${ }^{14} \mathrm{~N}_{2}{ }^{16} \mathrm{O}^{1} \mathrm{H}^{+},{ }^{14} \mathrm{~N}^{15} \mathrm{~N}^{16} \mathrm{O}^{+}$ \\
46 & ${ }^{30} \mathrm{Si}^{16} \mathrm{O}^{+}$ & ${ }^{46} \mathrm{Ca}^{+},{ }^{46} \mathrm{Ti}^{+}$ & ${ }^{14} \mathrm{~N}^{16} \mathrm{O}_{2}^{+},{ }^{46} \mathrm{Ca}^{16} \mathrm{O}^{+},{ }^{46} \mathrm{Ti}^{16} \mathrm{O}^{+}$ \\
60 & ${ }^{28} \mathrm{Si}^{16} \mathrm{O}_{2}^{+}$ & ${ }^{60} \mathrm{Ni}^{+}$ & ${ }^{44} \mathrm{Ca}^{16} \mathrm{O}^{+}$ \\
61 & ${ }^{29} \mathrm{Si}^{16} \mathrm{O}_{2}^{+}$ & ${ }^{61} \mathrm{Ni}^{+}$ & ${ }^{45} \mathrm{Sc}^{16} \mathrm{O}^{+}$ \\
62 & ${ }^{30} \mathrm{Si}^{16} \mathrm{O}_{2}^{+}$ & ${ }^{62} \mathrm{Ni}^{+}$ & ${ }^{46} \mathrm{Ti}^{16} \mathrm{O}^{+}$ \\
\hline
\end{tabular}

638 Table 3. List of potential polyatomic and isobaric interferences for silicon isotopes and ${ }^{\mathrm{x}} \mathrm{SiO}_{\mathrm{x}}{ }^{+}$ 639 ion species. Only major interferences for silicon isotopes are noted (after Engström et al[20].). 640 Potential polyatomic interferences for the ${ }^{\mathrm{x}} \mathrm{SiO}_{\mathrm{x}}{ }^{+}$ion species were found in the paper of May 641 T. W. and Wiedmeyer R. H.[21]. 


\begin{tabular}{|c|c|c|c|c|c|}
\hline \multirow[b]{2}{*}{${ }^{29} \mathrm{Si} /{ }^{28} \mathrm{Si}$} & \multicolumn{5}{|l|}{$\delta^{29} \mathrm{Si}(\% \mathrm{o})$} \\
\hline & $\sim 10$ & $\sim 30$ & $\sim 50$ & $\sim 70$ & $\sim 100$ \\
\hline Ratio value & $0.05145(20)$ & $0.05241(22)$ & $0.05339(17)$ & $0.05450(19)$ & $0.05598(20)$ \\
\hline$\%$ Uncertainty & 0.38 & 0.42 & 0.32 & 0.35 & 0.36 \\
\hline$\%$ Repeatability $(n=3)$ & 0.013 & 0.087 & 0.30 & 0.17 & 0.016 \\
\hline$\%$ Trueness & 0.19 & 0.03 & -0.08 & 0.01 & -0.12 \\
\hline Zeta-score & 0.98 & 0.16 & 0.50 & 0.06 & 0.62 \\
\hline \multicolumn{6}{|l|}{${ }^{30} \mathrm{Si} /{ }^{28} \mathrm{Si}$} \\
\hline Ratio value & $0.03354(13)$ & $0.03357(15)$ & $0.03352(13)$ & $0.03359(13)$ & $0.03361(14)$ \\
\hline$\%$ Uncertainty & 0.38 & 0.44 & 0.39 & 0.39 & 0.41 \\
\hline$\%$ Repeatability $(n=3)$ & 0.40 & 0.54 & 0.11 & 0.23 & 0.26 \\
\hline$\%$ Trueness & 0.015 & 0.09 & -0.08 & 0.11 & 0.14 \\
\hline Zeta-score & 0.08 & 0.38 & 0.43 & 0.55 & 0.66 \\
\hline
\end{tabular}

646 Table 4. Average values of isotope ratios, uncertainty, repeatability and trueness for different 647 silicon reference materials. Zeta-score was expressed according to ISO 13528[57]. Isotope 648 ratio uncertainties were calculated by taking into account uncertainties of the mass 649 fractionation factors $\left(\beta_{29 / 28}, \beta_{30 / 28}\right)$ and the measured silicon ratios. Isotope ratio repeatability 650 was calculated as the \%RSD for three measurements of the same solution. Trueness is 651 expressed as the difference between the average isotope ratio and the values of the reference 652 solutions. Uncertainty and repeatability are expressed for a coverage factor $k=2$. 


\section{Figure captions}

Figure 1. Three-isotope plot for ${ }^{\mathrm{x}} \mathrm{Si}^{16} \mathrm{O}^{+}$(open squares) and ${ }^{\mathrm{x}} \mathrm{Si}^{16} \mathrm{O}_{2}{ }^{+}$(open circles) ion species in Ultrapur $\mathrm{HNO}_{3}$ solutions with different concentrations. ${ }^{x} \mathrm{Si}^{16} \mathrm{O}^{+}$ratios are shifted away from the Exponential Mass Fractionation Law (EMFL) due to important polyatomic interferences. The good agreement of the ${ }^{\mathrm{x}} \mathrm{Si}^{16} \mathrm{O}_{2}{ }^{+}$ratios with the EMFL points to the absence of polyatomic interferences. Uncertainties of the ratios were calculated following the next equation: $2 \times \mathrm{SD} / \sqrt{ } \mathrm{n}$, were $S D$ is the Standard Deviation and $n$ the number of replicates per measurement, in this case $n=10$

Figure 2. Simplified schematic representation of the operating principle of the tandem mass spectrometer for silicon isotope ratio measurements, showing the advantageous use of ${ }^{\mathrm{x}} \mathrm{Si}^{16} \mathrm{O}_{2}{ }^{+}$ions species compared to ${ }^{\mathrm{x}} \mathrm{Si}^{16} \mathrm{O}^{+}$.

Figure 3. Evolution of the Relative Standard Deviation (\%RSD) of ${ }^{29} \mathrm{Si}^{16} \mathrm{O}_{2}{ }^{+} /{ }^{28} \mathrm{Si}^{16} \mathrm{O}_{2}{ }^{+}$ratio measurements (red dots) for: (a) different integration times for ${ }^{29} \mathrm{Si}^{16} \mathrm{O}_{2}{ }^{+}$and $1 \mathrm{~s}$ for ${ }^{28} \mathrm{Si}^{16} \mathrm{O}_{2}{ }^{+}$ and (b) different number of sweeps and fixed integration times (6 $\mathrm{s}$ for ${ }^{29} \mathrm{Si}^{16} \mathrm{O}_{2}{ }^{+}$and $1 \mathrm{~s}$ for ${ }^{28} \mathrm{Si}^{16} \mathrm{O}_{2}{ }^{+}$). Solid and dashed lines represent the counting statistics law for different integration times for ${ }^{28} \mathrm{Si}^{16} \mathrm{O}_{2}{ }^{+}$.

Figure 4. ${ }^{29,30} \mathrm{Si}^{16} \mathrm{O}_{2}{ }^{+} /{ }^{28} \mathrm{Si}^{16} \mathrm{O}_{2}{ }^{+}$ratios as a function of different Wait Time Offset. Uncertainties of the ratios were calculated following the next equation: $2 \times \mathrm{SD} / \sqrt{\mathrm{n}}$, were $S D$ is the Standard Deviation and $n$ the number of replicates per measurement, in this case $n=10$.

Figure 5. Three-isotope plot for ${ }^{29,30} \mathrm{Si}^{16} \mathrm{O}_{2}{ }^{+} /{ }^{28} \mathrm{Si}^{16} \mathrm{O}_{2}{ }^{+}$ratios before (blue dots) and after (red dots) abundance sensitivity optimization. For these measurements, a solution of $400 \mathrm{ng} \mathrm{g}^{-1}$ of the IRMM-018a was used. The solid line represents the Exponential Mass Fractionation Law (EMFL). Uncertainties of the ratios were calculated following the next equation: $2 \times \mathrm{SD} / \sqrt{ }$, were $S D$ is the Standard Deviation and $n$ the number of replicates per measurement, in this case $n=15$. 
691 Figure 6. Measurements of reference solutions with different ${ }^{29} \mathrm{Si}$ enrichment (red dots). Each 1692 solution was measured three times. Solid lines represent values of the referent solutions and 3693 dashed lines their uncertainties. Isotope ratio uncertainties were calculated for each individual 5694 measurement by propagating uncertainties of the mass fractionation factors and of the 695 measured silicon ratios. All uncertainties are expressed for a coverage factor $k=2$. Values of 696 isotope ratios, uncertainties, zeta-score, the method repeatability and trueness can be found in 697 table 4. 